\title{
The Impact of Brand Equity on Purchase Intensions with Modertaing Role of Subjective Norms
}

\author{
Syed Mehmood Shah, Muhammad Adeel, Faisal Hanif*, Mohsin Khan \\ Department of Management \& Social Sciences, Capital University of Science and Technology Islamabad, Pakistan
}

Copyright $\bigcirc 2016$ by authors, all rights reserved. Authors agree that this article remains permanently open access under the terms of the Creative Commons Attribution License 4.0 International License

\begin{abstract}
During the past couple of decades, brand equity has emerged as one of the key concepts in marketing. Literature concerned with consumer brand relationship is calling for more studies in order to increase understanding of brand equity dimensions. Therefore, this study aims to contribute to the existing body of knowledge by investigates the impact of brand equity, on consumers' brand purchase intention. We propose that subjective norms play a moderating role in this relationship. The data were gathered from 197 respondents from the twin cities of Pakistan: Islamabad and Rawalpindi. Results make known that subjective norms are found to positively moderate the relationship between brand equity and consumers' brand purchase intention. The study findings support for the hypotheses. Some managerial implications for retailer were also discussed.
\end{abstract}

Keywords Brand Equity, Purchase Intention, Subjective Norms

\section{Introduction}

During the last few decades brand equity remained the most dominant area for the marketing research [1]. Main reason for such domination of brand equity in marketing research is the marketers' wish of creating strong brand for the purpose of obtaining sustainable competitive advantages and differentiating their products from those of competitors $[2 ; 3]$.

From the consumer perspective many variables have been studied under brand equity umbrella such as brand awareness [4] brand associations [5]; brand loyalty [6] perceived quality [7] and [1] brand attitude [8] brand image [3] brand preference [9] and purchase intentions [5]. Purchase intention stand out to be an important indicator of consumer behavior [10]. Several studies have proved the positive relationship between brand equity and purchase intention [11; 12]. However the role played by the subjective norms in brand equity and consumer purchase intentions formation is limited investigated empirically.

Theory of reasoned action establishes that subjective norms are the basic determinants of intention formation. This explains that people intend to perform a behavior which is accepted by the society $[13 ; 14]$. Therefore this study assume that brand with high social acceptability will have higher chances to be purchased. [15] addressed the relationship between culture orientation and brand equity whereas, [16] investigated the impact of family on brand equity based on the fact that if family provide the positive information about a brand the equity of that brand will be increased. However none of these studies have considered the impact of subjective norms on the relationship of brand equity and purchase intentions. Thus the current study is projected to fill this gap by hypothesizing that subjective norms play a moderating role between the relation of brand equity and purchase intentions.

Understanding why consumers buy different products is a key challenge for marketers across all categories of products, from fast-selling consumer goods to High Street fashion. Brands play a pivotal role in shaping people's perceptions of products as well as being a focal point for the meaning and value that products have for different individuals. The clothes we wear in our daily lives often signify our status, occupation, mood and even cultural affiliations [46]. If a brand can provide value through form and function, then consumers can feel comfortable repurchasing the brand and possibly other products made by the same firm [2]. Over time, consumers can and do develop relationships with particular brands they purchase.

Understanding brands and consumer brand relationships is vital for any business seeking to improve its competitive advantage in the marketplace, be it a fashion retailer or a service provider operating under a clearly defined brand identity Clothing allows people to identify with others and identify themselves. The brand can also act as a pivot between a numbers of competing considerations. For instance, a garment brand may be particularly expensive, but rich in symbolic meaning. A "basics" clothing retailer on the 
other hand, may stock good-quality, reasonably priced, durable clothing brands, but have little to offer a consumer in terms of brand image experience. Clothing is also a product category where many factors influence the purchasing process and ultimate brand choice. Understanding brand selection in the fashion purchasing process not only allows valuable insight for fashion retailers, but for any business selling a product that is rich in meaning.

The purpose of this study is twofold first to know the impact of brand equity on consumer purchase intentions in fashion clothing brands in Pakistan and second to find out the moderating role played by the subjective norms on the relationship of brand equity and purchase intentions, which leads to formation of a theoretical model to study the relationship between brand equity and purchase intention. Results obtained will focus on the importance of brand equity and subjective norms for purchase intentions from the consumer's perspective, to take actions to better manage the purchase intentions.

\section{Literature Review}

\section{Brand Equity}

Over few decades Brand equity gain generous attention from researcher as well as from practitioners. Numerous classifications and contributions have been made to define and conceptualize brand equity $[2 ; 3 ; 5 ; 17]$. Whereas, the core concept of brand equity depicts that "the power of a brand lies in what resides in the minds and hearts of customers" [3]. Brand equity is categorized as customer-based brand equity and financial based [3;18]. Financial based brand equity is related to financial value generated by brand, which can be viewed as "the additional cash flow created by a brand" [19]. Brand equity can be defined as "the differential effect that brand knowledge has on consumer response to the marketing of that brand". Brand equity from the consumer perspective, focus of this study is defined as the incremental value added to a product by virtue of its brand [2]. The consumer's responses to a particular brand name [20]. Customer's subjective evaluation of a brand after its objectively perceive value [21].

A more precise definition commonly cited in marketing literature is by [2], who defined brand equity as the set of assets and liabilities that are linked to a brand, it maybe the brand name or its symbol which increase or decrease the value of product or services. [2] Conceptualized brand equity as a multidimensional concept and suggest five components: brand awareness, brand association, brand loyalty, perceived quality and other proprietary assets linked to a brand (IP right, patents, trademarks). Other proprietary assets are not taken into consideration because they are not related to consumer. Plenty of literature is based on [2] and [3] conceptualization of brand equity, [22; 23]. However [1] conducted a comprehensive study and defined consumer-based brand equity as "cognitive and behavioral brand equity at the individual consumer level" (p. 2), they developed a multidimensional scale for consumer-based brand equity, consist of four dimensions: brand awareness, perceived quality, brand loyalty, brand association.

Following are [2] conceptualization of brand equity

Brand awareness: Defined as "the ability of a buyer to recognize or recall that a brand is a member of a certain product category" [2]. It is the first step for building brand equity which can be created either by putting a point of interact, sense of familiarity with the brand which act as a signal of trust in consumer mind to consider the brand being valuable to buy.

Brand associations: Defined as "anything linked in memory to a brand" [2]. It represents the meaning of that particular brand for the consumer. The two dimensions awareness and associations are related to each other, because associations have some strength level [2;3], and these associations grow stronger with every new experience and exposure with brand [2;3]. Brand association is a source of product positioning and differentiation for the companies in the marketplace. Creating a favorable attitude for the brand $[2 ; 24]$, which increases the chances to purchase the product $[25 ; 5]$.

Brand loyalty: Brand loyalty is considered the most essential dimension of brand equity. [2, p. 39] defined brand loyalty as " the attachment that a customer has to a brand." While, [26] defined brand loyalty as a commitment to consume a preferred product or services in future which cause same brand consumption despite the situational factors or marketing efforts. Brand loyalty is defined from two perspectives attitudinal and behavior [27]. From an attitudinal perspective, focus of this study, brand loyalty focuses on the consumer attachment and repurchases intention by evaluating their preferences and attraction toward the brand [28]. From behavioral perspective brand loyalty mean a repeated consumption of the same brand which is observed in brand choices [29].

Perceived quality; "is the consumer's judgment about a product's overall excellence or superiority" [30, p. 3]. It is consumer's subjective evaluation of quality of the product. Perceived quality is considered another important dimension of brand equity as the higher the perceived Quality the higher the brand equity.

\section{Relation among Research Concepts}

\section{Brand Equity and Purchase Intentions}

We incorporated one consequence of brand equity: the purchase intention. The probability of buying the brand is called as purchase intention [45]. Purchase intention represents the possibility that consumers will plan or be willing to purchase a certain product or brand in future, then being an important indicator of consumer behavior [10]. Brand equity has been considered as a condition for brand preference, and therefore it affects purchase intention [31]. 
Several studies point out the positive relationship between the dimensions of brand equity, brand preference and the purchase intention [12]. There is empirical evidence suggesting that once consumers have tried a specific brand, it increases their proneness, enhancing the likelihood of purchasing that brand in future [32]. Most importantly, [17] further emphasize that all brand-equity components (brand loyalty, brand awareness/association, and perceived quality) can influence purchase intention. Moreover, research in consumer behavior illustrates that brand equity is the main element which directly influences the brand purchases [46].

\section{Subjective Norms and Purchase Intentions}

Subjective Norms meaning "the perceived social pressure to perform or not to perform the behavior" [33 p.188] also predict intentions of the behavior. It's the level of social force felt with regard to a specific behavior. In other words subjective norms are the perceived judgment of important others who influence an individual decision-making. While It Is also an individual's feelings of social force from other group or people [33]. Past research confirmed the positive relationship between subjective norms and behavioral intention $[34 ; 35 ; 36 ; 37]$. Whereas literature also suggest that Subjective Norms have a positive impact on Purchase Intentions [38]. But literature lacks in accordance to subjective norms.

\section{Moderating role of Subjective Norms}

A purchase intention is commonly considered an essential consequence of brand equity and several studies have proved the positive relation between brand equity and purchase intentions [1]. As past literature confirmed that the first two dimensions of brand equity, awareness and associations are interrelated to each other, and create a favorable attitude for the brand [2;31], which increases the likelihood of purchasing the product [5]. While brand loyalty from an attitudinal perspective is defined as the tendency to be loyal to a focal brand, which is demonstrated by developing favorable attitude toward the brand and the intention to buy [26]. The definition of perceived quality is very similar to attitude as its consumer's subjective evaluation or judgment about a product's overall superiority $[1 ; 30]$. Therefore perceived quality develops a positive attitude about the brand which leads to purchase intention. These four dimensions of brand equity form positive attitude about the brand. However, only positive attitude is not sufficient to predict behavioral intentions [13; 14].

As per Theory of Reasoned Action individuals' intentions would be predictors of their behavior and individuals' attitudes towards behavior and Subjective Norms are Antecedents of behavioral intention [13; 14]. Subjective norms are the necessary component of the theory of reason action as it has an impact on behavioral intention such as people close to the individual like family members' and other important people like friends perception influence the consumer decisions about the brand [39]. Therefore subjective norms influence the relationship between consumer attitude and purchase intention [40]. Consequently it is hypothesized that

Hypothesis 1. Brand Equity is significantly and positively correlated with purchase intention.

Hypothesis 2. Subjective Norms moderates the Brand equity and purchase intention.

\section{Theoretical Framework}

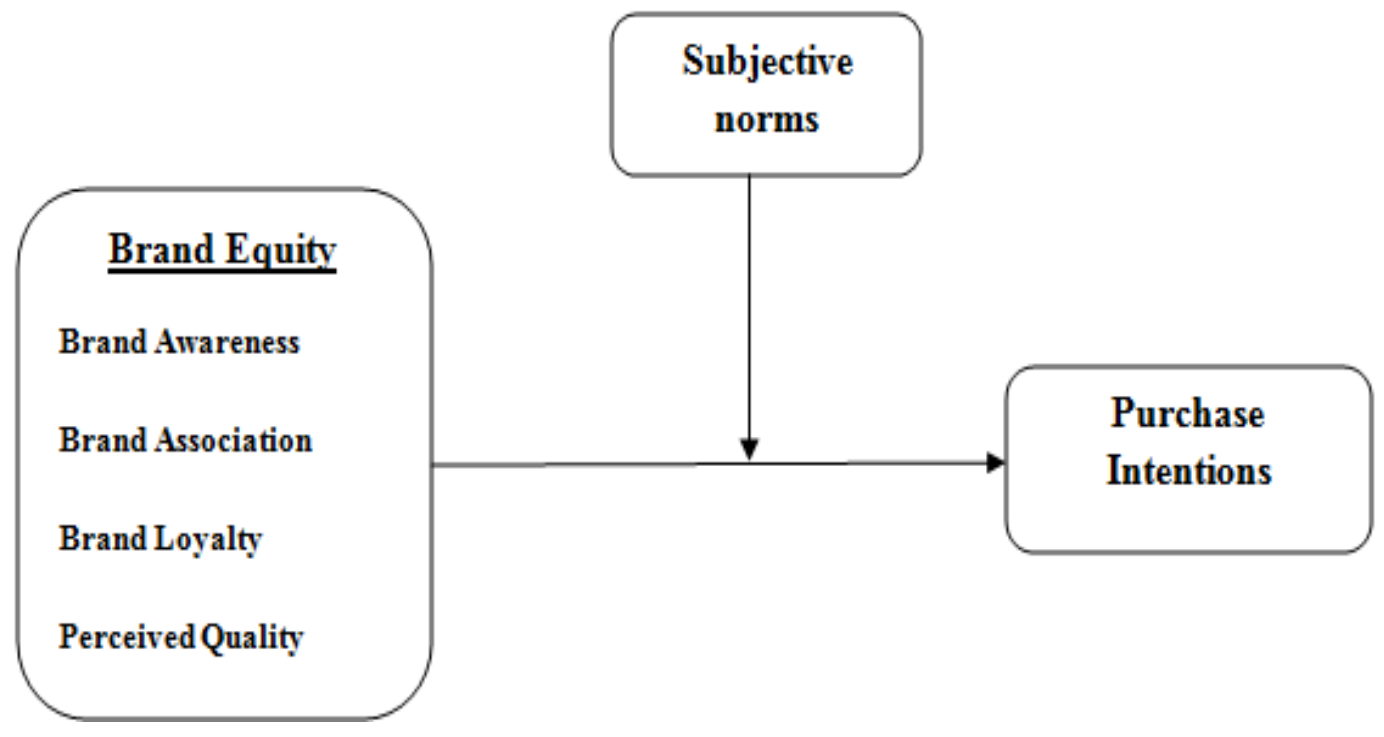


Current research is quantitative and data was collected from individuals through questionnaire survey. The research is causal as it confirmed the association among brand equity elements and purchase intention with moderating role of subjective norms. This study focused on clothing brands users in Islamabad and Rawalpindi.

\section{Methods}

\section{Measures}

All measures were obtained from a "self-report" questionnaire. All variables were measured using a 5 point Likert scale where $1=$ strongly disagree and $5=$ strongly agree. The instruments used for this study were adopted from existing researches that were previously validated.

The scales of brand equity were adopted from [1]. Brand equity scale consisted on ten items. They measured the brand equity through its four essential diminutions such as brand awareness, brand association, brand loyalty and perceived quality. The Cronbach's alpha reliability for this scale was observed to be 0.75 . Purchase intention was measured with a scale developed by [41]. The scale consisted of 3 items. The Cronbach's alpha reliability for this scale was observed to be 0.837 which is well above the acceptable value, thereby showing a very good reliability. Subjective norms scale consisted of 3 items, adapted from [36]. The Cronbach's alpha reliability for this scale was observed to be 0.855 .

\section{Sample and Procedure}

Subjects were aged between 18 and 28 and the gender split was approximately equal. The sample consisted of university undergraduate, graduate and postgraduate students, who represent an important market segment for fashion retailers and other retailers of branded merchandise. The use of a student sample is a weakness of the research, but the findings are still useful as a starting point for understanding fashion brand choice.

The sampling technique was convenient sample all the respondents were personally contacted. A cover letter explaining the purpose and scope of the study assured respondents of strict anonymity and that participation in the study was voluntary. Of the 300 surveys distributed, 45 went to the Riphah international University (responses, 31; response rate, $68 \%$ ), 100 to the Islamic international university (responses, 66; response rate, 66\%), 45 to the Capital university of Science and Technology Islamabad (responses, 30; response rate, 66\%), 30 to the Air university (responses, 21; response rate, $70 \%$ ), and 80 went to the FAST national university (responses, 49; response rate,
$61 \%)$.

Overall, from the 300 questionnaires distributed, we received 197 usable responses, representing a response rate of 66 percent. The respondents had a mean age of 24.81 years (s.d. 8.86), and 64 percent were male. Education levels ranged from graduate, to Ph.D., with 10.2 percent of the respondents having a M.S certificate and the remaining 89.8 percent doing bachelor degree in universities.

\section{Control Variables}

In keeping with prior studies [42; 43], Gender, Age and Educational level of respondent have been treated as control variables for all statistical analyses.

\section{Results}

\section{Correlation Analysis}

The very purpose of correlation is to indicate the relation between two variables or to examine whether the two variables move in similar or opposite directions

Table 1. Correlation Analysis

\begin{tabular}{ccccccc}
\hline & Variables & Mean & SD & $\mathbf{1}$ & $\mathbf{2}$ & $\mathbf{3}$ \\
\hline 1 & Brand Equity & 3.57 & 0.9453 & 1 & & \\
2 & Purchase Intention & 3.77 & 0.7002 & $.651^{* *}$ & 1 & \\
3 & Subjective Norms & 3.41 & 0.9485 & $.367^{* *}$ & $.225^{* *}$ & 1
\end{tabular}

**. Correlation is significant at the 0.01 level (2-tailed)

Table 1 shows the correlation coefficients between different variables of the study. The correlation coefficient ranges between -1 and +1 . A correlation value of above 0.5 depicts a strong positive association between the variables. Results indicate a statistically highly significant positive relationship of brand equity with purchase intention $\left(.651^{* *}\right)$, Subjective norms $\left(.367^{* *}\right)$. Purchase intention also has a statistically significant positive relationship with subjective norms $\left(.225^{* *}\right)$.

\section{Regression Analysis}

For drawing conclusions regarding the dependence of one variable on another, regression analysis is used. Regression shows the extent to which a variable depends on another, independent variable on which it is being regressed. After controlling demographic variables Gender, marital status, Age, Experience and Qualification, a regression analysis was executed between IV and DV. 
Table 2. Moderating Analysis

\begin{tabular}{cccc}
\hline & \multicolumn{3}{c}{ Dependent variable: Purchase intention } \\
\cline { 2 - 4 } & $\mathbf{B}$ & $\mathbf{R}^{2}$ & $\Delta \mathbf{R}^{2}$ \\
\hline Direct Effect: BE & $0.720^{* *}$ & 0.519 & $.128^{*}$ \\
Moderation & & & \\
Step 1 & & & $.557^{* *}$ \\
BE & .491 & & \\
SN & $.298^{*}$ & & $0.104^{* *}$ \\
Step 2 & & $0.867^{* *}$ & \\
BE x SN & & & \\
\hline
\end{tabular}

Control variables were Gender, Age and Qualification, ${ }^{* * *}<.001, \mathrm{BE}=$ Brand Equity, $\mathrm{SN}=$ Subjective Norms,

Moderated regression analysis as shown in table 2 was used to examine the interactive effects of Brand Equity and Subjective norms on Purchase Intention. After controlling control variables (Demographics) in the first of all in analysis checks the direct effect of the Brand Equity on Purchase intention that was positive and significant. Hence, it provides the support to our first variable. In the next step the check impact of Brand equity and subjective norms were controlled, then, in the last step, the interaction term (BEXSN) was entered, and the result was significant as shown in table 2 . The result of interacting factor (beta $=.438$ and $\mathrm{p}=.000)$ shows that subjective norms moderates relationship between Brand equity and Purchase intention. Hence, it provided support to the second proposed hypothesis that subjective norms moderate the relationship between Brand Equity and purchase intention. So the Regression matrix in above table shows that there is a direct relationship between Brand equity and purchase intention $\left(\beta=0.720^{* *}, \mathrm{R}^{2}=0.519\right.$, sig $\left.=0.000\right)$, and moderation results $\left(\beta=.438^{* *}, \mathrm{R}=0.867^{* *}, \Delta \mathrm{R}^{2}=0.104^{* *}\right.$, sig=0.000) indicates that subjective norms is playing a moderating role on the relationship between Brand equity and purchase intention.

\section{Discussion}

This study used a moderated analysis to investigate the effects of subjected norms on the relationship between brand equity and purchase intention among clothing Brands. The results clearly show that brand equity has significant and positive impact on the purchase intention, and the subjective norms also positively and significantly moderate the relationship between brand equity and purchase intention. Educated people are more attracted to use branded clothes because of the nature of their jobs or businesses. Mostly students are fascinated to engage in using clothing brands to fulfill their hedonic needs.

Our results provide some useful insights for retailers, since nowadays, they face the challenge of improving their brand management in order to increase brand equity and sale to offer a differential value to the marketplace [44]. As suggested in previous literature, in order to increase sales and market share of brand equity, retailers should put more emphasis on the social norm and their reputation, instead of positioning on a low price proposition. Purchase intention increases by improving the store image, since it is clear that the store image affects the private label brand's sales. Consequently, retailers should make consumers rely less on extrinsic cues such as price or packaging and focus instead on their store commercial image and brand equity.

Based on our findings, retailing managers can improve the purchase intention by increasing product and brand variety, improving product quality, offering good value for money and pleasantly decorating the store, given that these improvements increase the private labels' purchase intention. Awareness tries to improve the consumers' perception of their own brands. The development of commercial policies orientated to reinforcing their brand image an in this regard, various promotional activities, such as offering free samples or tasting at the point of sale could be put into practice.

By understanding customers and the roles that brands can play in purchasing, we believe retailers can better appreciate the sustainable drivers of brand value and brand equity in their businesses as well as isolating their competitive advantages over other retailers and manufacturers. Brands are an essential part of consumer choices when purchasing products, but to understand why this is the case, we suggest retailers need to isolate and understand the factors that underlie a brand's importance and what factors lead their own brands to possess a competitive advantage in the marketplace. Retailers could also examine how their own brands can affect departures from (or adherence to) rational choice in specific purchasing contexts. By understanding the role of brands as market based assets and the relationships that can develop between consumers and particular store and category brands, managers can not only enhance revenue generation, but also be in a better position to predict business outcomes, now and in the future.

\section{Limitations and Directions for Future Research}

Like in all research studies, the present study also has some limitations. Some of the limitations that were encountered during the research were that due to the shortage of time data could not be gathered from a large number of people. Another limitation lies in the use of convenience sampling technique and the limited number of variables that 
were focused upon in this research. Moreover, the sample consisted primarily of students and the study was conducted in the urban areas because of which the findings of this study cannot be generalized as the sample was not a good representative of the whole population. Future research is required to confirm the findings. Future research should include people from all domains of life and from other parts of the country in order to generalize the findings of the study. Other variables can also be considered such as brand loyalty and brand love.

\section{REFERENCES}

[1] Yoo, B., \& Donthu, N. (2001). Developing and validating a multidimensional consumer-based brand equity scale. Journal of business research, 52(1), 1-14.

[2] Aaker, D. (1991). Brand equity. La gestione del valore della marca.

[3] Keller, K. L. (2003). Brand synthesis: The multidimensionality of brand knowledge. Journal of consumer research, 29(4), 595-600.

[4] Aaker, D. (1990). Brand extensions: The good, the bad, and the ugly. MIT Sloan Management Review, 31(4), 47.

[5] Yoo, B., Donthu, N., \& Lee, S. (2000). An examination of selected marketing mix elements and brand equity. Journal of the academy of marketing science, 28(2), 195-211.

[6] Cobb-Walgren, C. J., Ruble, C. A., \& Donthu, N. (1995). Brand equity, brand preference, and purchase intent. Journal of advertising, 24(3), 25-40.

[7] Martin, G. S., \& Brown, T. J. (1990). In search of brand equity: the conceptualization and measurement of the brand impression construct. Marketing theory and applications, 2(1), 431-438.

[8] Li, H., Daugherty, T., \& Biocca, F. (2002). Impact of 3-D advertising on product knowledge, brand attitude, and purchase intention: The mediating role of presence. Journal of Advertising, 31(3), 43-57.

[9] Berry, L. L. (2000). Cultivating service brand equity. Journal of the Academy of marketing Science, 28(1), 128-137.

[10] Wu, P. C., Yeh, G. Y. Y., \& Hsiao, C. R. (2011). The effect of store image and service quality on brand image and purchase intention for private label brands. Australasian Marketing Journal (AMJ), 19(1), 30-39.

[11] Calvo-Porral, C., \& Lévy-Mangin, J. P. (2014). Private label brands: major perspective of two customer-based brand equity models. The International Review of Retail, Distribution and Consumer Research, 24(4), 431-452.

[12] Mayer, R. E. (2003). Elements of a science of e-learning. Journal of Educational Computing Research, 29(3), 297-313.

[13] Fishbein, M., \& Ajzen, I. (1975). Belief, attitude, intention and behavior: An introduction to theory and research.
[14] Ajzen, I., \& Fishbein, M. (1980). Understanding attitudes and predicting social behaviour.

[15] Jung, J., \& Shen, D. (2011). Brand equity of luxury fashion brands among Chinese and US young female consumers. Journal of East-West Business 17(1), 48-69.

[16] Bravo Gil, R., Fraj Andres, E., \& Martinez Salinas, E. (2007). Family as a source of consumer-based brand equity. Journal of Product \& Brand Management, 16(3), 188-199.

[17] Kim, E. Y., Knight, D. K., \& Pelton, L. E. (2009). Modeling brand equity of a US apparel brand as perceived by Generation $\mathrm{Y}$ consumers in the emerging Korean market. Clothing and Textiles Research Journal, 27(4), 247-258.

[18] Chaudhuri, A. (1995). Brand equity or double jeopardy?. Journal of product \& brand management, 4(1), 26-32.

[19] Chen, C. C., Chen, P. K., \& Huang, C. E. (2012). Brands and consumer behavior. Social Behavior and Personality: an international journal, 40(1), 105-114.

[20] Shocker, A. D., Srivastava, R. K., \& Ruekert, R. W. (1994). Challenges and opportunities facing brand management: An introduction to the special issue. Journal of Marketing Research, 149-158.

[21] Rust, R. T., Zeithaml, V. A., \& Lemon, K. N. (2004). Customer-centered brand management. Harvard business review, 82(9), 110-120.

[22] Kim, J. H., \& Hyun, Y. J. (2011). A model to investigate the influence of marketing-mix efforts and corporate image on brand equity in the IT software sector. Industrial Marketing Management, 40(3), 424-438.

[23] Chang, H. H., \& Liu, Y. M. (2009). The impact of brand equity on brand preference and purchase intentions in the service industries. The Service Industries Journal, 29(12), $1687-1706$

[24] Christodoulides, G., \& De Chernatony, L. (2010). Consumer-based brand equity conceptualization and measurement: A literature review. International journal of research in marketing, 52(1), 43-66.

[25] Cheng-Hsui Chen, A. (2001). Using free association to examine the relationship between the characteristics of brand associations and brand equity. Journal of product \& brand management, 10(7), 439-451.

[26] Oliver, R. L. (1997). Satisfaction: A behavioral perspective on the consumer. New York: McGraw-Hill.

[27] Chaudhuri, A., \& Holbrook, M. B. (2001). The chain of effects from brand trust and brand affect to brand performance: the role of brand loyalty. Journal of marketing, 65(2), 81-93.

[28] Russell-Bennett, R., McColl-Kennedy, J. R., \& Coote, L. V. (2007). Involvement, satisfaction, and brand loyalty in a small business services setting. Journal of Business Research, 60(12), 1253-1260.

[29] Pappu, R., Quester, P. G., \& Cooksey, R. W. (2005). Consumer-based brand equity: improving the measurement-empirical evidence. Journal of Product \& Brand Management, 14(3), 143-154. 
[30] Zeithaml, V. A. (1988). Consumer perceptions of price, quality, and value: a means-end model and synthesis of evidence. The Journal of marketing, 2-22.

[31] Netemeyer, R. G., Krishnan, B., Pullig, C., Wang, G., Yagci, M., Dean, D \& Wirth, F. (2004). Developing and validating measures of facets of customer-based brand equity. Journal of Business Research, 57(2), 209-224.

[32] Steenkamp, J. B. E., \& Dekimpe, M. G. (1997). The increasing power of store brands: building loyalty and market share. Long range planning, 30(6), 917-930.

[33] Ajzen, I. (1991). The theory of planned behavior. Organizational behavior and human decision processes, 50(2), 179-211.

[34] Butler, L. M., Kobati, G. Y., Anyidoho, N. A., Colecraft, E. K., Marquis, G. S., \& Sakyi-Dawson, O. (2012). Microcredit-nutrition education link: A case study analysis of ghanaian women's experiences in income generation and family care. African Journal of Food, Agriculture, Nutrition and Development, 12(1), 5709-5724.

[35] Han, H., Hsu, L. T. J., \& Sheu, C. (2010). Application of the theory of planned behavior to green hotel choice: Testing the effect of environmental friendly activities. Tourism Management, 31(3), 325-334.

[36] Taylor, S., \& Todd, P. (1995). Decomposition and crossover effects in the theory of planned behavior: A study of consumer adoption intentions. International journal of research in marketing, 12(2), 137-155.

[37] Tonglet, M., Phillips, P. S., \& Read, A. D. (2004). Using the Theory of Planned Behaviour to investigate the determinants of recycling behaviour: a case study from Brixworth, UK. Resources, Conservation and Recycling, 41(3), 191-214.

[38] Amin, H., Rahim Abdul Rahman, A., Laison Sondoh Jr, S., \&
Magdalene Chooi Hwa, A. (2011). Determinants of customers' intention to use Islamic personal financing: The case of Malaysian Islamic banks. Journal of Islamic Accounting and Business Research, 2(1), 22-42.

[39] Johar, M., \& Rammohan, A. (2006). Demand for microcredit by Indonesian women, 29: School of Economics and Political Science. Faculty of Economics and Business, University of Sydney.

[40] Jebarajakirthy, C., \& Lobo, A. C. (2014). War affected youth as consumers of microcredit: An application and extension of the Theory of Planned Behaviour.Journal of retailing and consumer services, 21(3), 239-248.

[41] Yoo, B., Donthu, N., \& Lee, S. (2000). An Examination of Selected Marketing Mix Elements and Brand Equity. Journal of the Academy of Marketing Science, 28(2), 195-211.

[42] Little, T. D., Card, N. A., Bovaird, J. A., Preacher, K. J., \& Crandall, C. S. (2007). Structural equation modeling of mediation and moderation with contextual factors. Modeling contextual effects in longitudinal studies, 1 .

[43] Beristain, J. J., \& Zorrilla, P. (2011). The relationship between store image and store brand equity: A conceptual framework and evidence from hypermarkets. Journal of Retailing and Consumer Services, 18(6), 562-574.

[44] Keller, K. L. (2013). Strategic Brand Management: Building, Measuring and Managing Brand Equity. [4th Edition] Boston: Pearson Education.

[45] Esch, F. R., Langner, T., Schmitt, B. H., \& Geus, P. (2006). Are brands forever? How brand knowledge and relationships affect current and future purchases. Journal of Product \& Brand Management, 15(2), 98-105.

[46] Levy, S. (1959). Symbols for Sale. Harvard Business Review, (Nov-Dec) 117-124. 